\title{
Photochemical Studies on Composite Resins Cured by Visible Light
}

\author{
Hiroshi SHIMOMURA \\ Department of Operative Dentistry, Showa University School of Dentistry, 2-1-1 Kitasenzoku, Ohta-ku, \\ Tokyo 145, Japan
}

Received on December 26, 1986

Accepted on April 2, 1987

The characteristics of the method of curing resin using visible light was examined, photochemically.

Commercially available light curing units emitted much unnecessary light, predominantly in a long wavelength range. The internal hardness of cured resins increased with argon ion laser output along with deep hardness, but the maximum hardness was not always increased. The degree of polymerization of the commercially available composite resins measured using a laser Raman spectrophotometer was about 55 $-70 \%$, which indicated that there is ample room for improvement. The degree of polymerization of bonding agents in dentinal tubule determined by laser Raman microspectroscopy was about $80-85 \%$.

Key words : Visible light curing resin, Curing characteristic, Laser Raman spectroscopy

\section{INTRODUCTION}

Until recently paste or paste type resins were the preferred material for restoration. These systems utilize benzoylperoxide and tertiary amines for the initiation of polymerization. The first light curing system, the Nuva System, was marketed by Caulk and Co. This system, which uses benzoin methyl ether as a photosensitizer and which is activated by irradiation with ultraviolet light, has not been popular because it produces a poor curing depth, has harmful radiation effects and has other problems. A better system in which visible light is used for curing was developed by Imperial Chemical Industries Ltd. of England. This product was first marketed by Johnson and Johnson under the trade mark of Fotofil. The polymerization system of this product was based upon a photo-redox activation system which reacted upon exposure to blue light. The activity seemed to be accelerated by dlcamphorquinone which served as a photosensitizer. In addition, the compound contained a trace of benzil, various types of tertiary amines, reboflavin, methylene blue etc.

The characteristics of this method of curing resin are reported.

\section{MATERIALS AND METHODS}

1) Light absorption characteristics of the photosensitizer, camphorquinone.

To determine the light absorption characteristics of the photosensitizer dlcamphorquinone, the component of visible light curing resin systems reacting most sensitively to visible light, this compound was dissolved in benzene and its light absorption measured by using a spectrophotometer*

2) Light absorption characteristics of light curing resins.

\footnotetext{
* Type 320, HITACHI, Tokyo, Japan
} 
The light curing resins were dissolved in a mixture of $80 \%$ methylene chloride and $20 \%$ ethylacetate. Then, the filler was removed by spinning and the light absorption measured with a spectrophotometer*.

3) Irradiation experiments utilizing monochromatic light to establish the optimal wavelength for polymerization.

To confirm the polymerization characteristics as assumed from the previously established data for light absorption of the photosensitizer and the visible light curing resins, the depth of curing was measured after exposure to monochromatic light (laser) of different wavelengths, all other conditions kept the same. First an Argon ion laser** capable of producing a wavelength of about $470 \mathrm{~nm}$ was used. Then a variable wavelength light source was used. Though this latter laser could emit light of eight wavelengths, the beams having wavelengths of 514.5 and $488.0 \mathrm{~nm}$ were particularly strong while those having wavelengths of 472.7 and $465.8 \mathrm{~nm}$, were weak.

Except for the two weak beams, the remaining six monochromatic light beams were regulated to $50 \mathrm{mw}$. The depth of curing was measured for various types of visible light curing resins (mainly universal shade) which had been filled into stainless steel moulds. The steel moulds had an inner diameter of $6 \mathrm{~mm}$ and a depth of $12 \mathrm{~mm}$. All samples were exposed to visible light for 20 seconds. To study the polymerization characteristics at shorter wavelengths, an Organic dye laser*** and nitrogen exited lasers**** were used. The equipment used for measuring the curing depth of resins was the same as that used for the Argon ion laser**.

Six light beams of a well-defined wavelength between 430 and $480 \mathrm{~nm}$ at $10 \mathrm{~nm}$ intervals were provided by changing the dyes according to demand, tuning the nitrogen exited laser**** to the proper frequency.

4) Wavelength characteristics of various types of curing units emitting visible light.

The light which was emitted by the light curing unit was compensated for time variation by measuring the intensity of the light with a monochrometer***** which was equipped with a step scan unit. At the same time the relative intensity (radiation energy) of the light at each wavelength was measured with a spectrofluorometer " while scanning at a constant rate from 350 to $650 \mathrm{~nm}$.

The graph was obtained by multiplication with a correction factor which was provided by a spectral radiation standard supplied by the manufacturer.

5) Experiment for identification of the optimal emission of monochromatic lightinternal hardness of resin cured with the available visible light curing units and output of various types of lasers.

A resin was subjected to irradiation with an Optilux \#\# unit and to an Argon ion laser** having a wavelength of $488.0 \mathrm{~nm}$. The output was adjusted to $50,100,200$ and $300 \mathrm{mw}$.

** Type GLG-3200, NEC, Tokyo, Japan

*** Type DL14, Molectron, Sunny Vale, CA, USA

**** Type UV24, Molectron, Sunny Vale, CA, USA

***** Type P-250, Nikon, Tokyo, Japan

\# Type A FP-550, Jasco, Tokyo, Japan

\# Visible light curing unit, Demetron, Danbury, CT, USA 
Following irradiation, the samples were immersed into distilled water for 24 hours at $37^{\circ} \mathrm{C}$. The hardness was then measured after the samples had been loaded with $10 \mathrm{~g}$ for 30 seconds. The hardness readings were taken with a Knoop microhardness tester $\#$. The measurements were performed along the central longitudinal axis starting from $0.1 \mathrm{~mm}$ below the irradiated surface, the interval between readings being $0.5 \mathrm{~mm}$. The average value of a reading was obtained by measuring three samples each.

6) Measurement of the degree of polymerization by means of laser Raman spectroscopy.

Two types of tertiary amines were used, DMAEM and DMPT. As shown in Table 1, a photosensitizer, $\mathrm{CQ}$ is used for initiation of the polymerization. In the following, $\mathrm{CQ}$ is referred to as a photosensitizer. As resin base monomers; 3G, Bis-MPEPP-2.6E, $-4 \mathrm{E}$, Bis-GMA and UDMA were used. These are usually used in various types of available resins as shown in Table 1. Figure 1 shows the molecular structures of $\mathrm{CQ}$ and DMAEM.

of the marketed visible light curing resins, four types were used for anterior and two types for posterior restoration, as shown in Table 2-(a). All the experiments were conducted at a room temperature of $23 \pm 2{ }^{\circ} \mathrm{C}$ and at a humidity of $50 \pm 10 \%$.

a) Measurement of the Raman spectrum of various types of base resin.

Using a laser Raman spectrophotometer \#\#\#, first the Raman spectra of the base resins was measured as shown in Table 1. As the light source, an argon ion laser \#\#\#\# was used. The wavelength of the light was $514.5 \mathrm{~nm}$ which is not absorbed by the photosensitizer. The output was $600 \mathrm{mw}$.

b) Differences in the degree of polymerization with the type of monomer and the photosensitizer system.

Table 1 Photosensitizer

\begin{tabular}{l} 
CQ dl-Camphorquinone \\
DMAEM \\
N,N-dimethylaminoethylmethacrylate \\
DMPT N,N-dimethyl-para-toluidine \\
Base Resin Monomer \\
Tri-EDMA (3G) \\
Tri-ethylene glycol dimethacrylate \\
Bis-MPEPP 2.6E, 4E \\
2,2-bis (4-methacryloxypolyetoxyphenyl)-propane \\
Bis-GMA \\
2,2-bis (p-2'-hydroxy-3'methacryloxypropoxyphenyl) propane \\
UDMA Di (methacryloxyethyl) trimethylhexamethylene di-urethane \\
\hline
\end{tabular}

=:= Model MVK-E, Akashi, Tokyo, Japan

=:z= Model R-2D, Shimazu, Kyoto, Japan

:=::= Type 165, Spectra Physics, Mountain View, CA, USA 
(a)

Table 2 Material Tested

\begin{tabular}{|c|c|c|c|c|}
\hline Brand Name & Manufacturer & Batch No. & Base Resin & Indication \\
\hline Durafil & Kulzer & $84136 \mathrm{U}$ & $\begin{array}{c}\text { Bis-GMA } \\
\text { UDMA }\end{array}$ & $\begin{array}{c}\text { Anterior } \\
\text { restoration }\end{array}$ \\
\hline Prisma-fil & Caulk & 929811 & Bis-GMA & $/ 1$ \\
\hline Silux & $3 \mathrm{M}$ & $5502 \mathrm{U}$ & Bis-GMA & $/ 1$ \\
\hline Visar-fil & Den Mat & 3802 & $\begin{array}{c}\text { Bis-MPEPP } \\
4 E\end{array}$ & / \\
\hline Ful-fil & Caulk & 81782 & $\begin{array}{c}\text { Bis-GMA } \\
\text { restoration }\end{array}$ \\
\hline Heliomolar & Vivadent & 540184 & $\begin{array}{c}\text { Bis-GMA } \\
\text { UDMA }\end{array}$ & / \\
\hline
\end{tabular}

(b)

\begin{tabular}{|c|c|c|c|}
\hline Brand Name & Manufacturer & \multicolumn{2}{|c|}{ Batch No. } \\
\hline \multirow{2}{*}{ Clearfil new bond } & \multirow{3}{*}{ Kuraray } & universal & N U628 \\
\cline { 3 - 4 } & \multirow{2}{*}{ Sankin } & catalyst & N C257 \\
\cline { 3 - 4 } Pyrofil bond & \multirow{2}{*}{$3 \mathrm{M}$} & catalyst & Q01 \\
\hline \multirow{2}{*}{ Scotch bond } & liquid & Q01 \\
\cline { 3 - 4 } & & resin & $7533 \mathrm{~L}$ \\
\hline
\end{tabular}

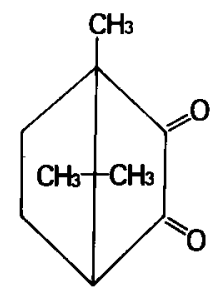

(a)

dI-C amphorquinone<smiles>C=C(C)C(=O)OCCN(C)C</smiles>

(b)

N. N-dimethylaminoethy Imethacrylate

Fig. 1 The molecular structures of $\mathrm{CQ}$ and DMAEM.

Bis-MPEPP 2.6E, Bis-GMA and UDMA were mixed with $3 \mathrm{G}$ at a molar ratio of $1: 1$ for all experiments. The strength of the Raman line was usually determined from area measurement and the Raman line was sharp when $1615 \mathrm{~cm}^{-1}$ was used as a reference. After establishment of the relationship between area measurement and base line measurement the latter was used. Area measurement was used when $1710 \mathrm{~cm}^{-1}$ was used as a reference, because the Raman line was rather wide. The cell for the Raman spectra measurements was a transparent glass tube having a diameter of $6 \mathrm{~mm}$ and a height of $20 \mathrm{~mm}$. 
To measure the degree of polymerization, samples were placed in the cell and irradiated and cured for 30 seconds with an Optilux unit; this unit emitted visible light. The direction of irradiation was parallel to the central longitudinal axis. Then the Raman transmission spectrum was measured by passing a laser beam along the same major axis.

c) The effect of different monomers on the degree of polymerization.

The experiment was repeated for 5 resins using $0.5 \mathrm{~mol} \% \mathrm{CQ}$ and $1.0 \mathrm{~mol} \% \mathrm{DMAEM}$, which increases the degree of polymerization.

d) Measuring light curing of composite resins on the market.

Commercially available light curing composite resins as shown in Table 2-(a), all have a Raman line at $1640 \mathrm{~cm}^{-1}$ as measured by laser Raman spectroscopy. Furthermore, they contain a great amount of filler which emit fluorescence heavily when exposed to Raman light during measurement. Because of this, the usual measuring methods are inadequate.

Consequently, aluminum foil was pasted onto the wedge shaped samples and the integrating time of the spectrophotometer was extended by slowing down the scanning speed.

Measurements were taken after fluorescence had been removed by aging. The degree of polymerization was determined by measuring the irradiated surface of the sample in a glass cell $4 \mathrm{~mm}$ in inner diameter and $1 \mathrm{~mm}$ tall. The samples were exposed for 30 seconds to light from an Optilux unit, the exposure coming from a lower transversal direction.

e) Measuring the chemical reaction of bonding agents for commercial composite resins.

First the Raman spectrum of each individual component (universal/catalyst or liquid/ resin) was measured as shown in Table 2-(b).

Then these commercial bonding agents for composite resins were mixed in a ratio of 1 : 1 for the experiments. The cell for the Raman spectrum measurements was a transparent glass tube having a diameter of $4 \mathrm{~mm}$ and a height of $10 \mathrm{~mm}$.

The Raman spectrum of the samples placed in the cell were determined by passing a laser beam along the central axis.

Next, the degree of polymerization of bonding agents in the dentinal tubule was measured by microspectroscopy. After specimens were prepared, the dentin surface was treated with $37 \%$ phosphoric acid solution for 1 minute, cleaned with water and dried under a soft jet of air for 30 seconds. Mixtures of the bonding agent (Clearfil new bond) were applied to the exposed surface. After the bonding agent had cured, self-curing resin (Clearfil F-II) was filled into the cavity. The samples were immersed into distilled water for 24 hours at $37^{\circ} \mathrm{C}$. The measurements were performed by using a laser Raman spectrophotometer ${ }^{\dagger}$ with a beam size of about $1 \mu \mathrm{m}$ in diameter.

\section{RESULTS}

1) Light absorption of the photosensitizer, camphorquinone.

As shown in Fig. 2, light absorption had peaks in the vicinity of $470 \mathrm{~nm}$, fell off rapidly at wavelengths longer than $490-500 \mathrm{~nm}$ and fell off slowly at shorter wavelengths.

2) Light absorption characteristics of a visible light curing resin.

†ype NR-1000, Jasco, Tokyo, Japan 


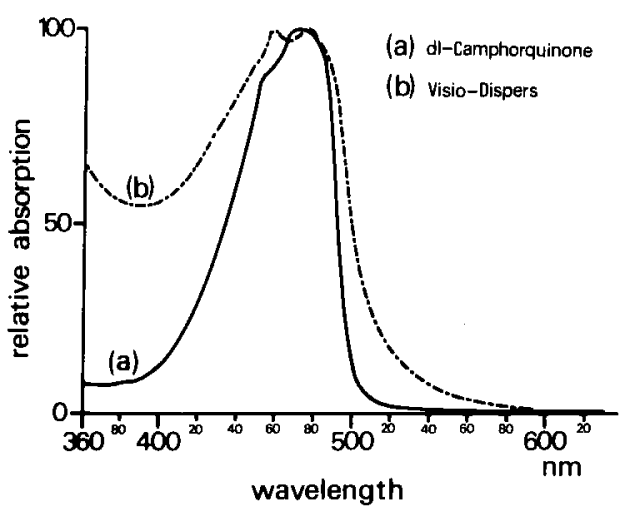

Fig. 2 Light absorption characteristics of the photosensitizer (dl-camphorquinone) and visible light curing resin (Visio-Dispers).

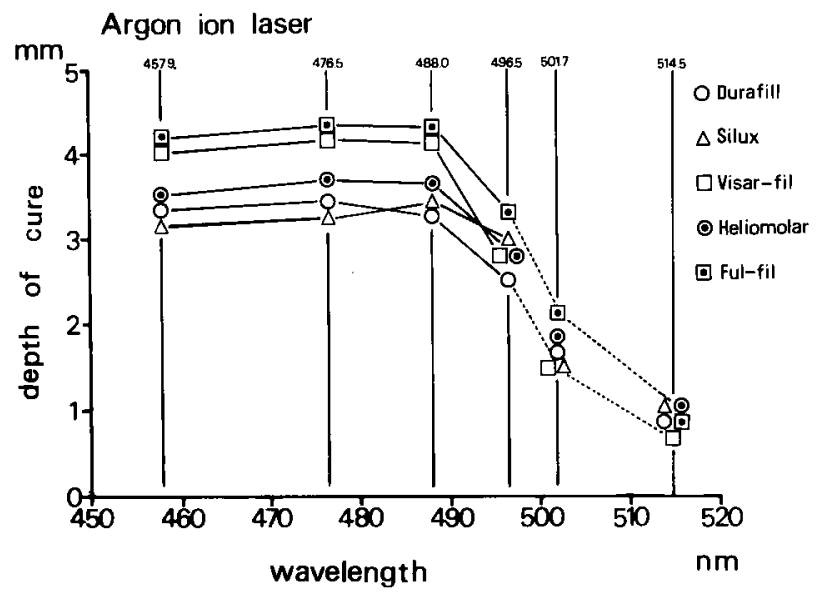

Fig. 3 The depth of curing of irradiation experiments using an argon ion laser.

Figure 2 shows the light absorption characteristics of Visio-Dispers as a representative example of absorption characteristics strikingly similar to those of camphorquinone.

3) Identification of the optimal wavelength for polymerization by means of irradiation experiments using a single wavelength.

Figure 3 shows that the curing is deepest at $476.5 \mathrm{~nm}$ and $488.0 \mathrm{~nm}$. Though slightly smaller at the shorter wavelength of $457.9 \mathrm{~nm}$, the depth of curing rapidly fell off from 496 . 5 to $501.7 \mathrm{~nm}$ and at $514.5 \mathrm{~nm}$ hardly no curing occurred.

With the organic dye laser, the depth decreased slowly at shorter wavelengths with a peak at $470 \mathrm{~nm}$ as shown in Fig. 4.

The polymerization characteristics of resins obtained with various types of monocromatic light from argon ion and dye lasers were quite similar to the light absorption 


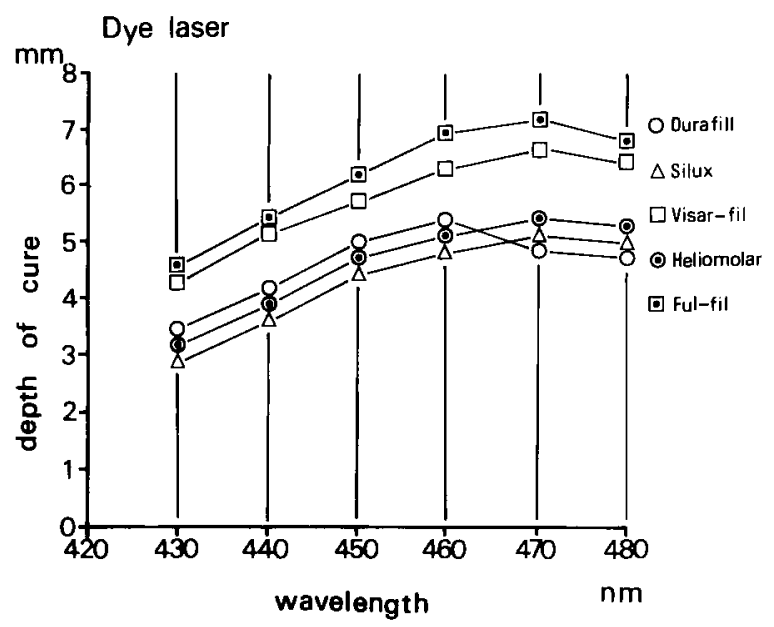

Fig. 4 The depth of curing of irradiation experiments using an organic dye laser.

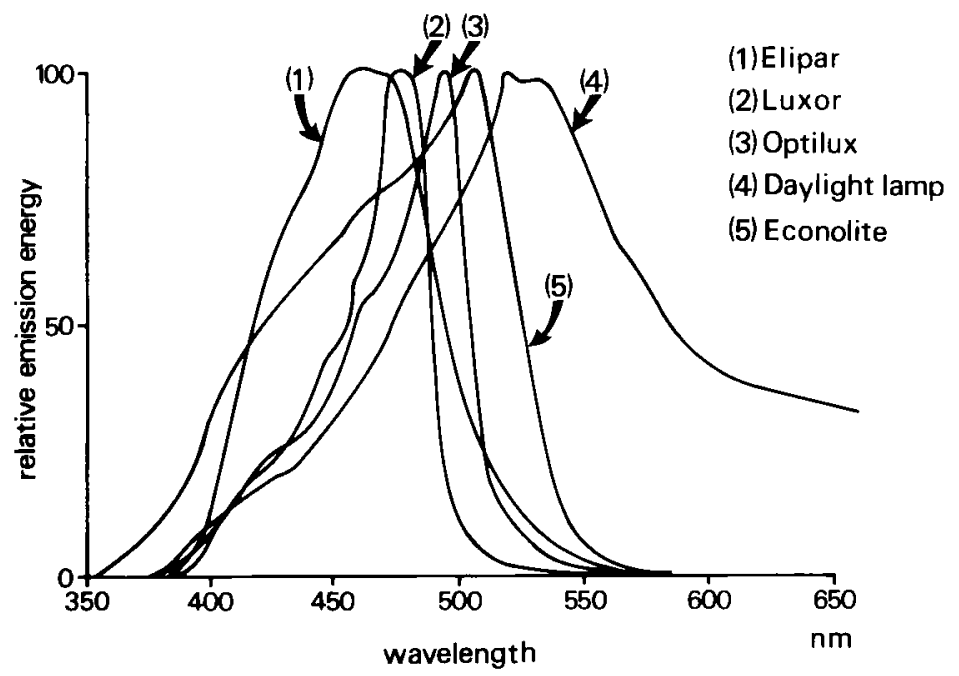

Fig. 5 Photospectrum of various visible light curing units.

characteristics of the photosensitizer and the resin.

4) Wavelength characteristics of various types of curing units that emit visible light.

Figure 5 shows the photospectrum of various light curing units. Light having a wavelength shorter than $400 \mathrm{~nm}$ is cut off neatly by all types and light of a wavelength longer than $500 \mathrm{~nm}$ is amply available as it is not filtered.

5) Identification of the optimal radiation by experiments using irradiation with a single wavelength. 

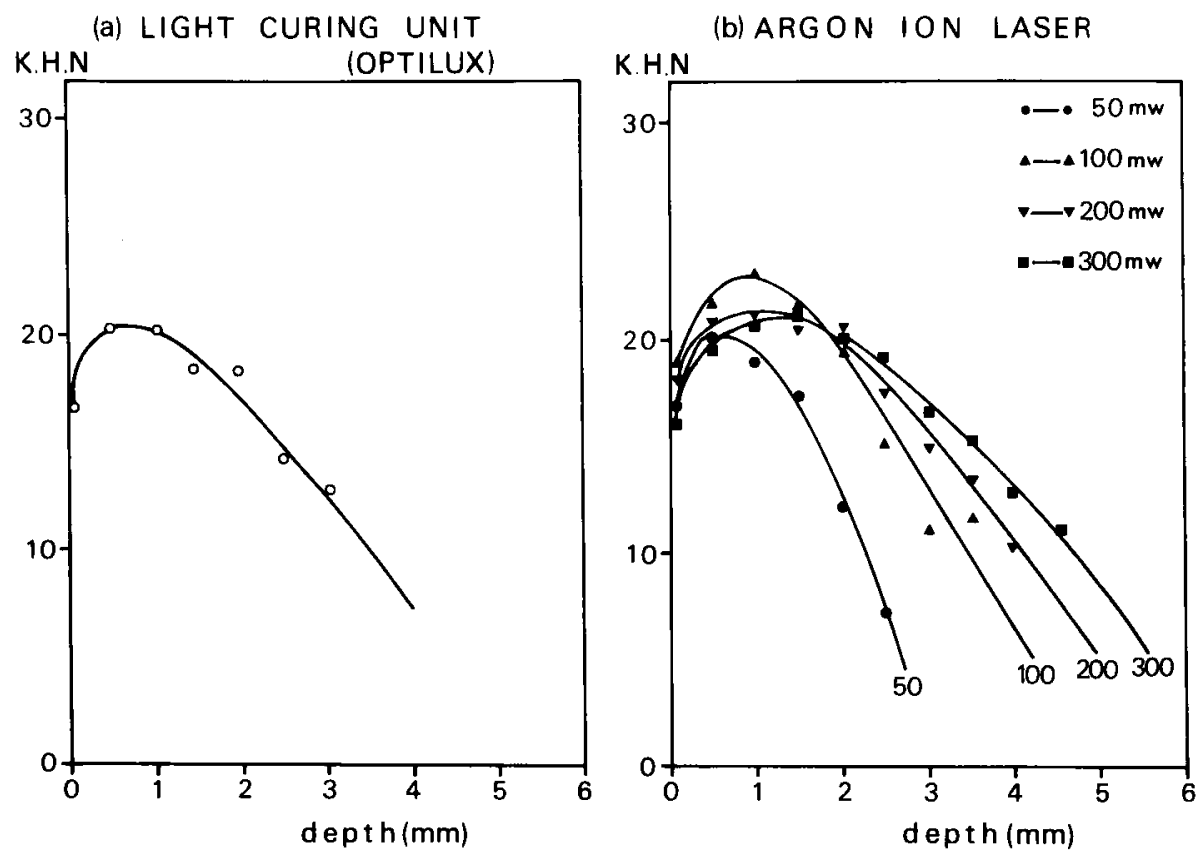

Fig. 6 Internal hardness of resin cured with a visible light curing unit (Optilux) and an argon ion laser.

Figure 6-(a) shows the results of Silux cured with Optilux. The hardness had a peak 0. $5 \mathrm{~mm}$ from the surface, and decreased beyond a depth of $1.0 \mathrm{~mm}$.

The results in Fig. 6-(b) were obtained when the output of the light source was exchanged with a laser having a wavelength of $488.0 \mathrm{~nm}$. Increase in the output of the laser from 50 to $100 \mathrm{mw}$ generally increases the hardness in all depths, and a maximum hardness is obtained at a depth of app. $1 \mathrm{~mm}$. A further increase in output to 200 and $300 \mathrm{mw}$ results in a reduction in the maximum hardness, the depth of which seems to increase; at the same time a greater hardness at larger depths is observed.

6-a) Measurement of Raman spectra of various types of base resin.

Figures 7 and 8 show the results of Raman spectroscopic readings taken at 1400-1800 $\mathrm{cm}^{-1}$, the other parameters being time constant $0.7 \mathrm{~s}$, integrating time $1.0 \mathrm{~s}$, scanning speed 10 $\mathrm{cm}^{-1} / \mathrm{min}$ and slit width $4.0 \mathrm{~cm}^{-1}$. As indicated in Figs. 7-(b) and 8-(c), for the resins Bis-MPEEP 2.6E, Bis-GMA which have a benzene ring in the molecule, a Raman line from the $\mathrm{C}=\mathrm{C}$ double bond (stretching vibration) of the nonreacting benzene ring appears at 1615 $\mathrm{cm}^{-1}$. By contrast, with the resins Tri-EDMA (3G) and UDMA which do not have a benzene ring, a Raman line does not appear at $1615 \mathrm{~cm}^{-1}$ as shown in Figs. 7-(a) and 8-(d).

For every resin base monomer, a Raman line of $1640 \mathrm{~cm}^{-1}$ appeared corresponding to the double bond stretch vibration of vinyl groups (monovalent unsaturated hydrocarbon group) at both ends of the directly reacting molecules. Also a Raman line of $1710 \mathrm{~cm}^{-1}$, corresponding to a double bond stretch reaction of $\mathrm{C}=0$ which did not react, appeared. 
(a) Tri-EDMA (3G)

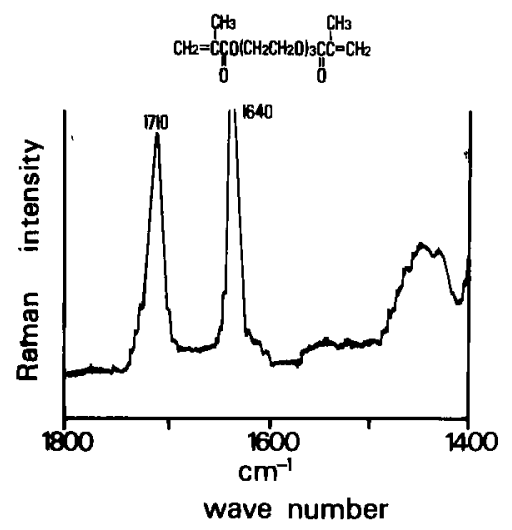

(b) Bis-MPEPP 2.6E

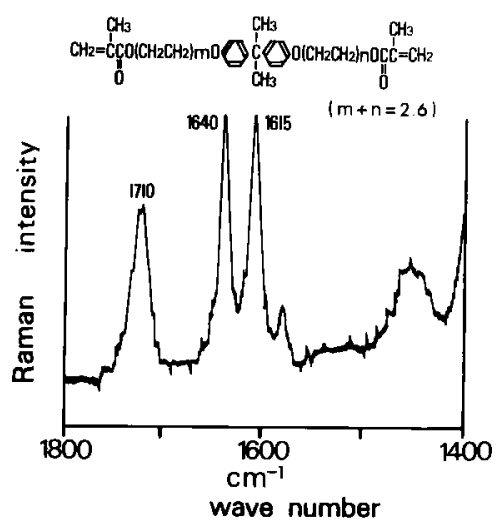

Fig. 7 Raman spectrum of $3 \mathrm{G}$ and Bis-MPEPP $2.6 \mathrm{E}$ at $1400-1800 \mathrm{~cm}^{-1}$. (time constant $-0.7 \mathrm{~s}$, integrating time- $-1.0 \mathrm{~s}$, scanning speed $-10 \mathrm{~cm}^{-1} / \mathrm{min}$, slit width $-4.0 \mathrm{~cm}^{-1}$ )

(c)

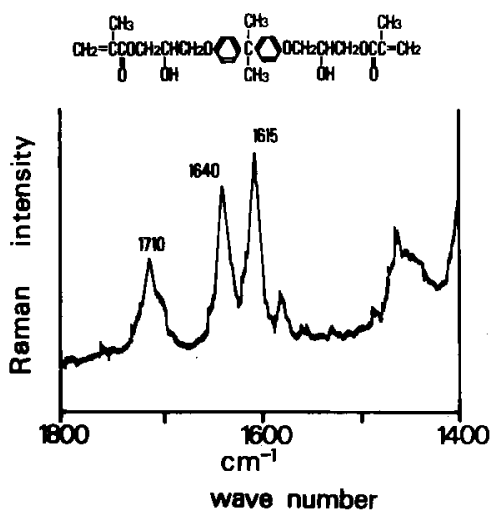

(d) UDMA
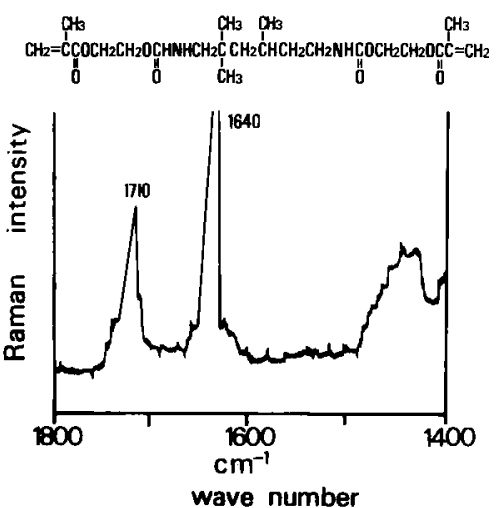

Fig. 8 Raman spectrum of Bis-GMA and UDMA at $1400-1800 \mathrm{~cm}^{-1}$. (time constant $-0.7 \mathrm{~s}$, integrating time- $1.0 \mathrm{~s}$, scanning speed $-10 \mathrm{~cm}^{-1} / \mathrm{min}$, slit width -4.0 $\mathrm{cm}^{-1}$ )

6-b) The differences in the degree of polymerization with the type of monomer and of the photosensitizer system.

Figures 9 and 10 show the polymerization of four kinds of monomers with various types of photosensitizers. For the combination of CQ and DMAEM, a concentration of $0.5 \mathrm{~mol} \%$ $\mathrm{CQ}$ and $1.0 \mathrm{~mol} \%$ DMAEM gave a markedly high polymerization, while lowering CQ to 0.2 mol\% and DMAEM to $0.4 \mathrm{~mol} \%$ markedly lowered polymerization. Polymerization decreased significantly for the resins $3 \mathrm{G}$ and Bis-GMA when high concentrations such as 1.0 mol\% CQ and 2.0 mol\% DMAEM were used, though not significantly compared to when Bis-MPEPP 2.6E and UDMA were used with $0.5 \mathrm{~mol} \% \mathrm{CQ}$ and $1.0 \mathrm{~mol} \%$ DMAEM. 
(a) $\operatorname{Tri}-\mathrm{EDMA}$ (3G)

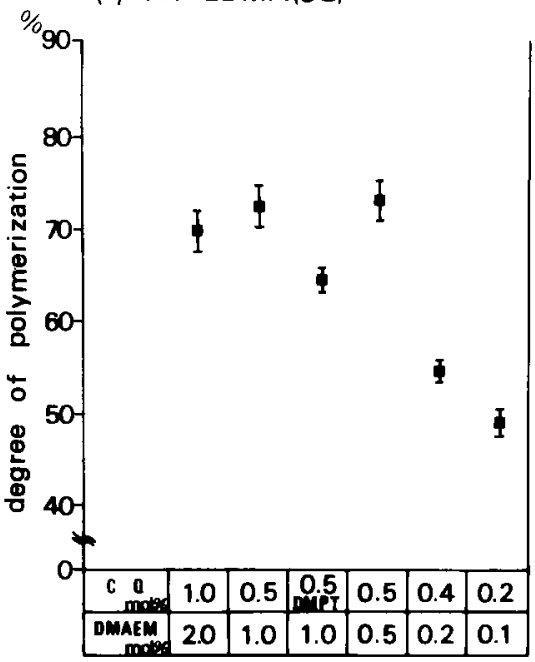

(b) Bis-MPEPP 2.6E +3G

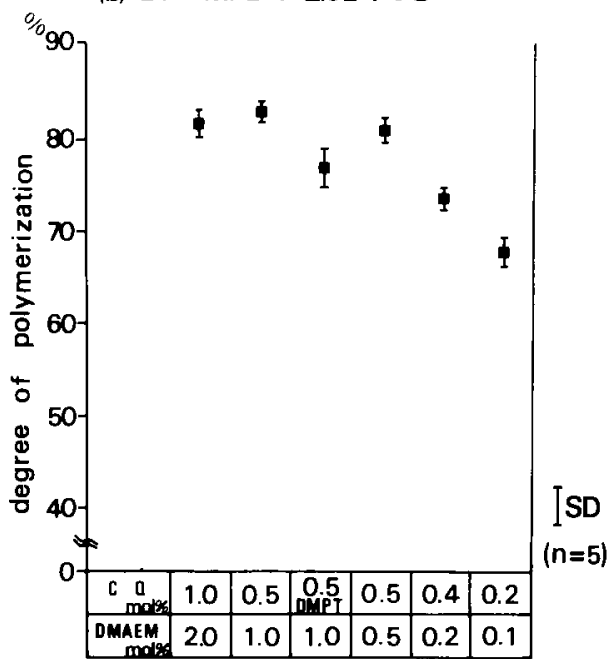

Fig. 9 Degree of polymerization of $3 \mathrm{G}$ and Bis-MPEPP 2.6E using various types of photosensitizers.

(c) Bis-GMA+3G

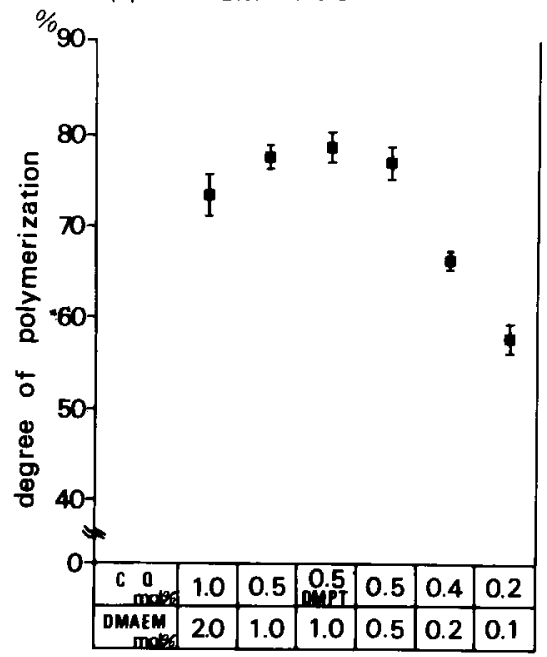

(d) UDMA +3G

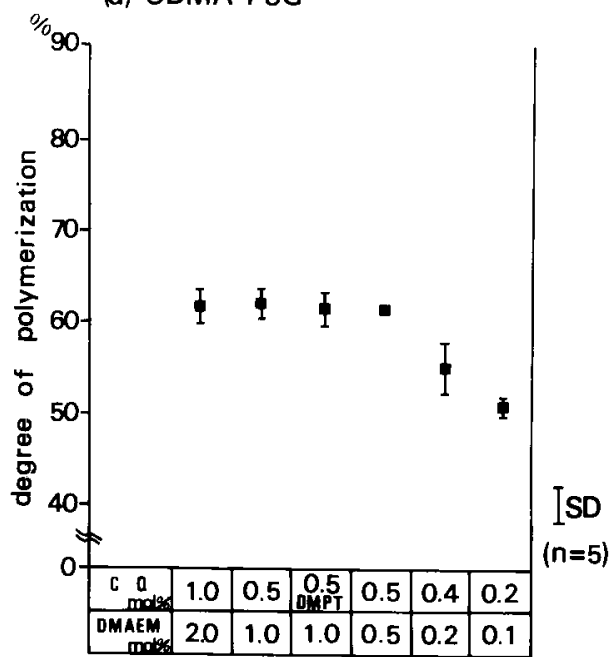

Fig. 10 Degree of polymerization of Bis-GMA and UDMA using various types of photosensitizers.

A change in the tertiary amine from $1.0 \mathrm{~mol} \%$ DMAEM to $1.0 \mathrm{~mol} \%$ DMPT in $0.5 \mathrm{~mol} \%$ $\mathrm{CQ}$ markedly lowered the polymerization of $3 \mathrm{G}$ and Bis-MPEPP $2.6 \mathrm{E}$ although a significant drop was not seen for Bis-GMA and UDMA.

6-c) The degree of polymerization with various monomers. 
(a)

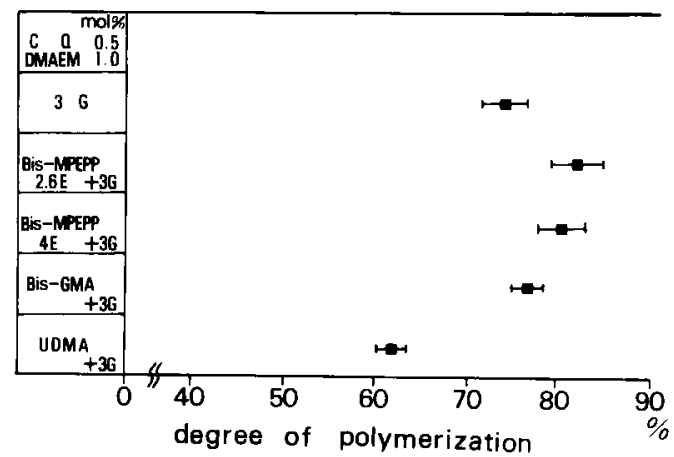

(b)

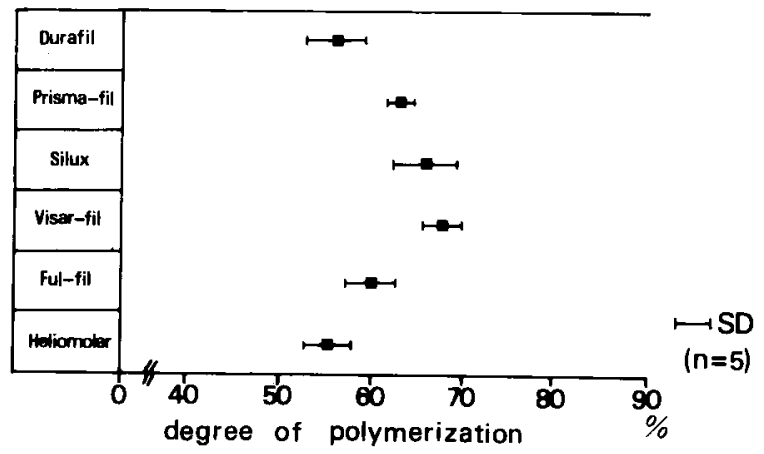

Fig. 11 Degree of polymerization of different monomers using $0.5 \mathrm{~mol} \% \mathrm{CQ}$ and 1.0 mol\% DMAEM and various visible light curing composite resins.

Figure 11-(a) shows the measurements of the degree of polymerization by $0.5 \mathrm{~mol} \% \mathrm{CQ}$ and $1.0 \mathrm{~mol} \%$ DMAEM for five types of monomers. The degree of polymerization decreased in the order of $2.6 \mathrm{E}$ or $4 \mathrm{E}$ of Bis-MPEPP followed by 3G, Bis-GMA and UDMA.

6-d) Measurement using commercially available composite resins cured by visible light.

Figure 11-(b) shows the degree of polymerization of four commercial types of resin for anterior restorations and two commercial types for posterior restorations, all resins being of visible light curing types. The degree of polymerization falls in the range of about $55-70 \%$, Visar-fil using Bis-MPEPP $4 \mathrm{E}$ as a base monomer which showed the highest degree of polymerization.

6-e) Figures 12-17 show the results of Raman spectroscopic readings taken at $800-1800$ $\mathrm{cm}^{-1}$. The other parameters were time constant $1.0 \mathrm{~s}$, integrating time $1.5 \mathrm{~s}$, scanning speed $20 \mathrm{~cm}^{-1} / \mathrm{min}$ and slit width $4.0 \mathrm{~cm}^{-1}$. Figures 12,14 and 16 show five characteristic bands $(890$, $1060,1100,1280,1460 \mathrm{~cm}^{-1}$ ) which indicate the presence of ethylalcohol. As shown in Figs. 13 and 17, the Clearfil new bond and Scotch bond which both have a benzene ring in the molecule displayed a peak at $1615 \mathrm{~cm}^{-1}$. In contrast the Pyrofil bond which does not have a benzene ring did not show the Raman line at $1615 \mathrm{~cm}^{-1}$ appearing in Fig. 15. Figure 18 shows the 


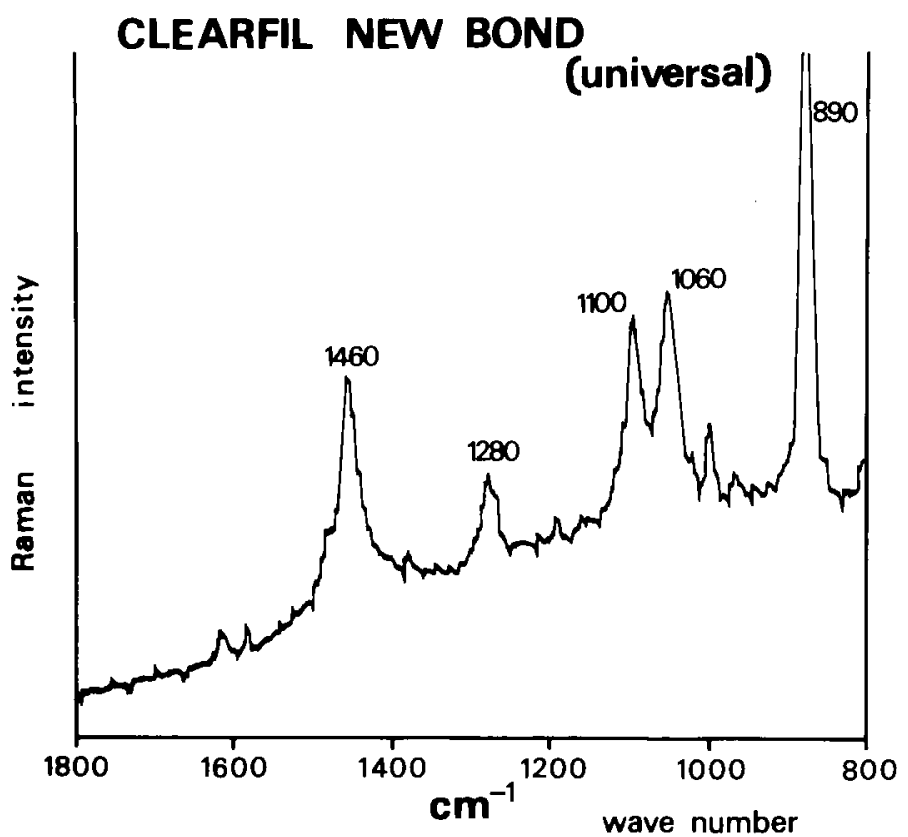

Fig. 12 Raman spectrum of Clearfil new bond (universal) at $800-1800 \mathrm{~cm}^{-1}$. (time constant- $1.0 \mathrm{~s}$, integrating time- $1.5 \mathrm{~s}$, scanning speed $-20 \mathrm{~cm}^{-1} / \mathrm{min}$, slit width $-4.0 \mathrm{~cm}^{-1}$ )

CLEARFIL NEW BOND

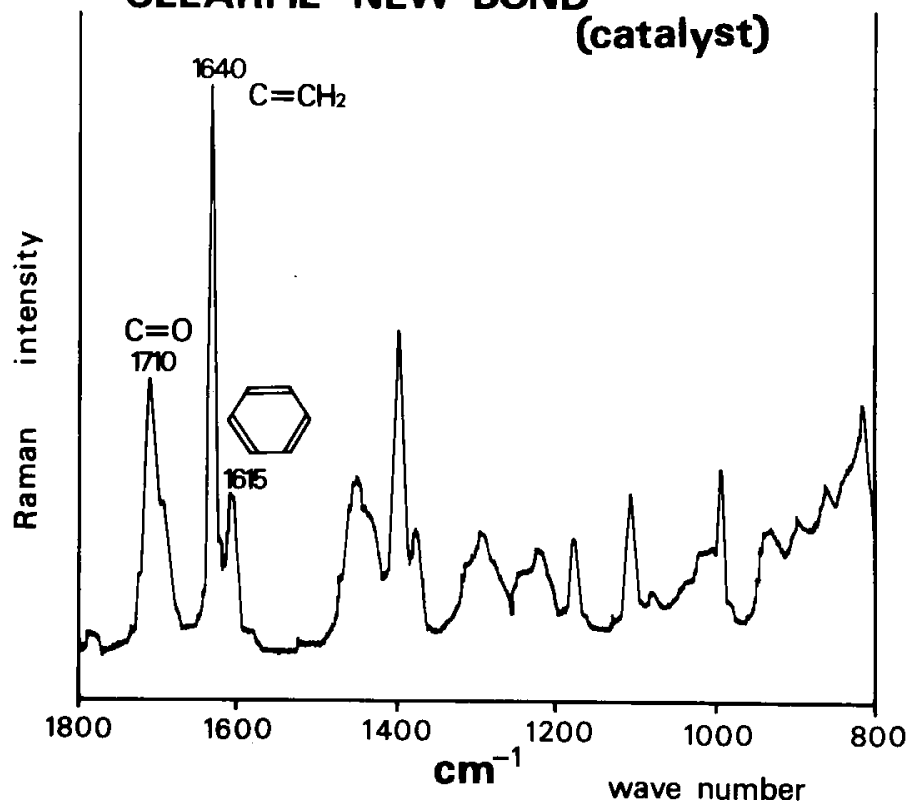

Fig. 13 Raman spectrum of Clearfil new bond (catalyst) at $800-1800 \mathrm{~cm}^{-1}$. (time constant-1.0 s, integrating time- $1.5 \mathrm{~s}$, scanning speed $-20 \mathrm{~cm}^{-1} / \mathrm{min}$, slit width $-4.0 \mathrm{~cm}^{-1}$.) 


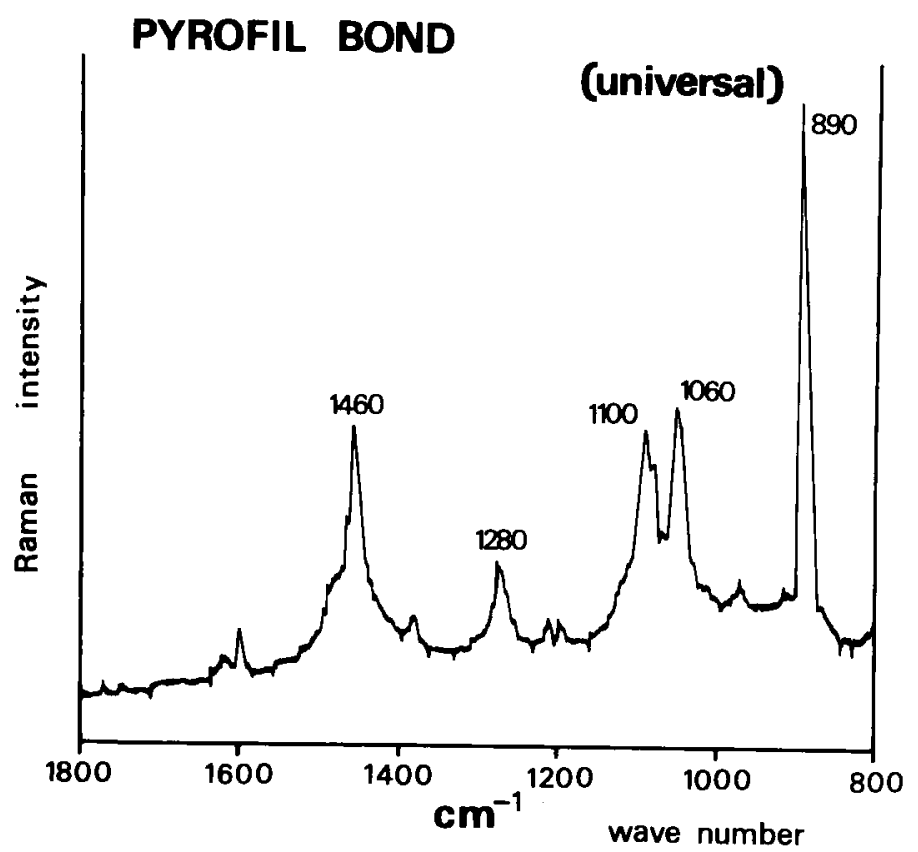

Fig. 14 Raman spectrum of Pyrofil bond (universal) at $800-1800 \mathrm{~cm}^{-1}$. (time constant$1.0 \mathrm{~s}$, integrating time- $1.5 \mathrm{~s}$, scanning speed $-20 \mathrm{~cm}^{-1} / \mathrm{min}$, slit width $-4.0 \mathrm{~cm}^{-1}$ )

\section{PYROFIL BOND}

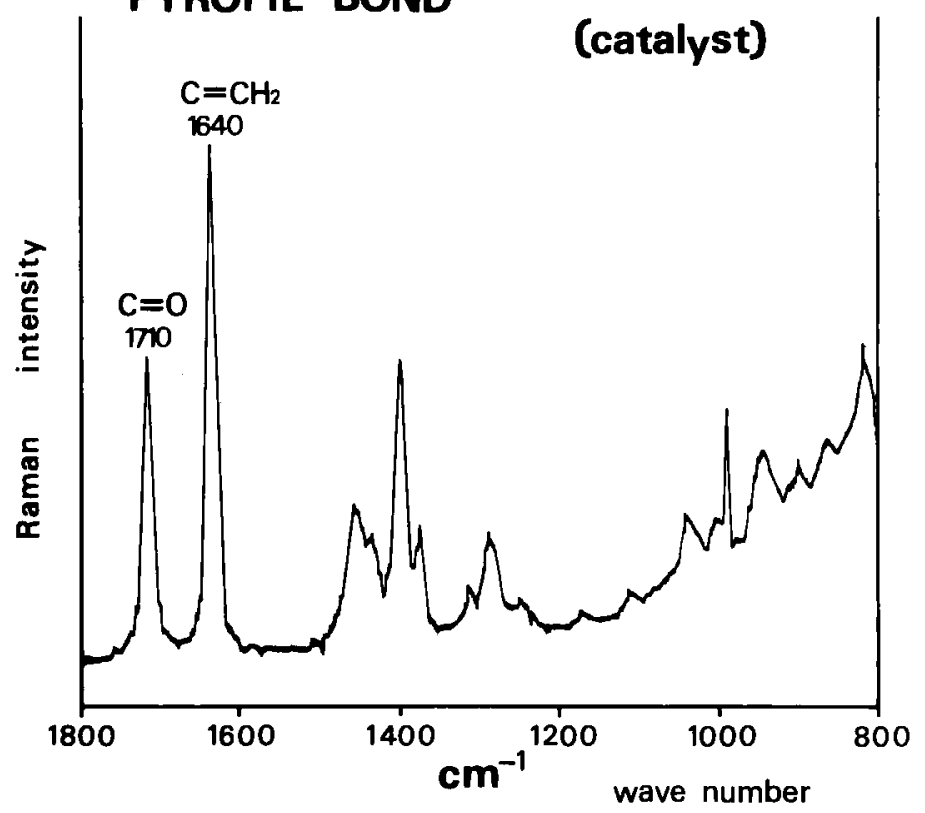

Fig. 15 Raman spectrum of Pyrofil bond (catalyst) at $800-1800 \mathrm{~cm}^{-1}$. (time constant$1.0 \mathrm{~s}$, integrating time-1.5 s, scanning speed $-20 \mathrm{~cm}^{-1} / \mathrm{min}$, slit width $-4.0 \mathrm{~cm}^{-1}$.) 


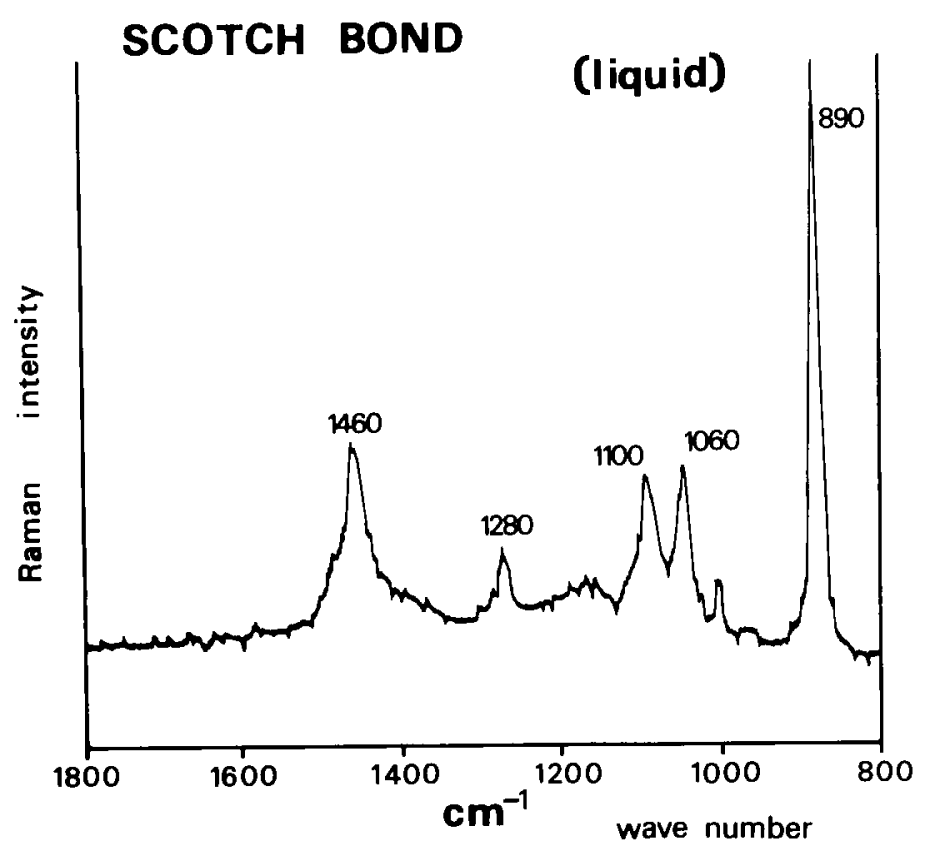

Fig. 16 Raman spectrum of Scotch bond (liquid) at $800-1800 \mathrm{~cm}^{-1}$. (time constant $-1.0 \mathrm{~s}$, integrating time- $1.5 \mathrm{~s}$, scanning speed $-20 \mathrm{~cm}^{-1} / \mathrm{min}$, slit width- $4.0 \mathrm{~cm}^{-1}$.)

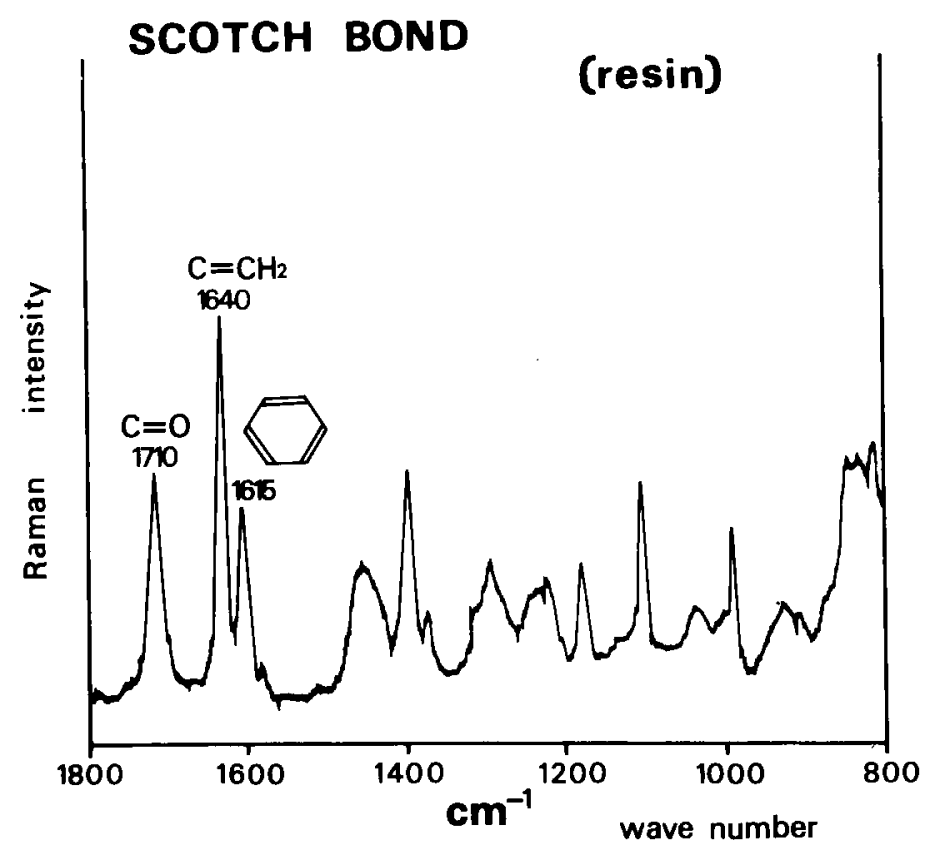

Fig. 17 Raman spectrum of Scotch bond (resin) at $800-1800 \mathrm{~cm}^{-1}$. (time constant-1.0 s, integrating time- $1.5 \mathrm{~s}$, scanning speed $-20 \mathrm{~cm}^{-1} / \mathrm{min}$, slit width $-4.0 \mathrm{~cm}^{-1}$.) 


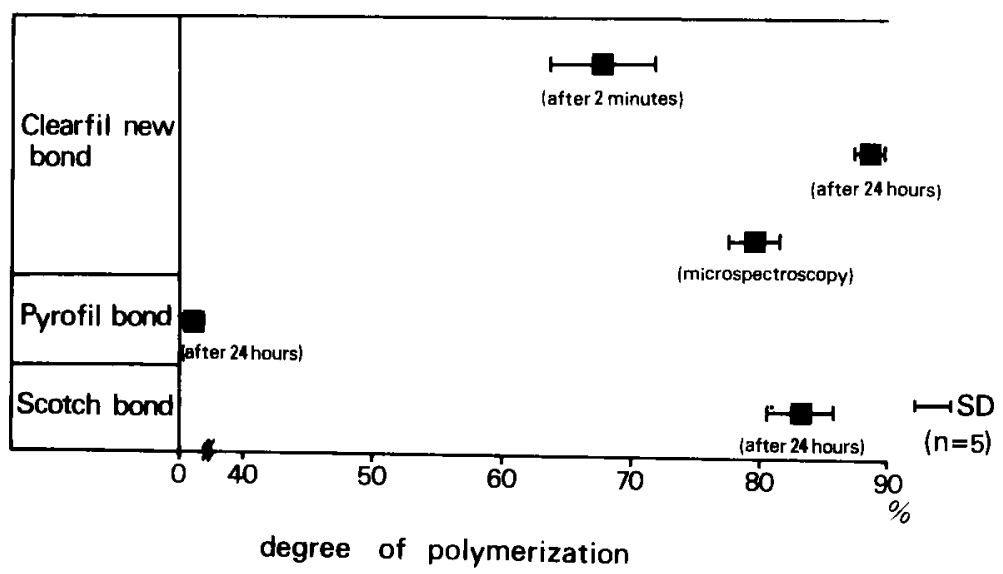

Fig. 18 Degree of polymerization of various bonding agents of commercially available composite resins.

polymerization of three kinds of bonding agents. There were no significant differences between Clearfil new bond and Scotch bond, but Pyrofil bond was not cured. The degree of polymerization of bonding agents (Clearfil new bond) in the dentinal tubule was about 80 $-85 \%$.

\section{DISCUSSION}

(1) Wave length and depth of cure

The ideal photospectrum for curing resins which can be cured by visible light, would probably coincide with the light absorption characteristics of the photosensitizer of the resin system obtained with monochromatic light.

That is, the optimal wavelength is $470-480 \mathrm{~nm}$ and falls off rapidly beyond $490-500 \mathrm{~nm}$. Longer wavelengths only are not necessary for polymerization and should be cut off with a filter. At wavelengths shorter than $470 \mathrm{~nm}$ the activity of light attenuates slowly and wavelengths shorter than $400 \mathrm{~nm}$ should be cut off because they are harmful to human tissue. (2) Microhardness and light intensity

To examine the polymerization characteristics, the microhardness of the resin was measured from the surface to the bottom at several points after the resin had been cured by exposure to visible light from an Optilux unit or an argon ion laser. With exposure to light from an Optilux unit, the hardness of the resin immediately under the surface (depth $0.1 \mathrm{~mm}$ ) was small, and reached a maximum at a depth of $0.5-1.0 \mathrm{~mm}$. The hardness then decreased with increasing depth. The hardness just below the irradiated surface is less than that slightly inside. Even if radiation is given through polyester strips, the polymerization is supposedly hindered by the oxygen in the atmosphere. Likewise, the reduction in hardness beyond a certain maximum depth is considered to be due to incomplete curing due to reduaed optical penetration. 
In the cases where an argon ion laser is used, the hardness generally increases as the output is raised from 50 to $100 \mathrm{mw}$, while the maximum hardness is not increased any further even though the output is raised to 200 and $300 \mathrm{mw}$. Rather a reduction in hardness is observed. When the light intensity is too high the molecular weight of the resin is assumed to be reduced through development of free radicals as well as by increased polymerization initiation due to the larger effective molecular weight of polymerized resin. Other factors such as degradation through exothermic reactions may also be involved. Several mechanisms and processes are still unaccounted for and remain to be elucidated in the future.

Generally the depth of a certain hardness increases with output as at the same time the hardness at a certain depth also increases. However, in this experiment no increase in hardness in relation to increased output, could be observed. Even with a laser beam having a considerable intensity in relation to the irradiated area, there is a limit to the depth to which light can penetrate into the resin sample.

(3) Degree of polymerization

Investigation with composite resin covering not only application and physical properties but also chemical composition and characteristics of the composite resin are still necessary. Composite resins can probably be cured by a chemical reaction, ultraviolet rays or visible light. However, the quality of polymerization seems greatly to affect clinical development. In practice, a low degree of polymerization may cause pulpal irritation due to diffusion of a residual monomer near the dental pulp ${ }^{11}$. In addition low polymerization is considered to cause attrition or abrasion due to reduced physical properties.

Furthermore, the degree of polymerization is generally considered to correlate with polymerization shrinkage, and polymerization shrinkage to be closely related with adhesion to the tooth. Microhardness measurement, high speed liquid chromatography and infrared spectrophotometry have been reported ${ }^{4,8-10}$ as methods for measuring the polymerization degree of resins. Microhardness and polymerization degree are not positively related, and the true degree of polymerization is hard to determine through measurement with high speed liquid chromatography which cannot completely recognize unpolymerized monomers. Measurement with an infrared spectrophotometer cannot be done without grinding the sample. With laser Raman spectrophotometry the polymerization degree of a sample can be measured without any prior treatment of the sample.

The Raman effect was theoretically predicted by Smekal ${ }^{12)}$ in 1923 , and first observed experimentally by $\operatorname{Raman}^{13)}$ in 1928.

For the monomers, 3G, Bis-MPEPP 2.6E, Bis-GMA, and UDMA, the highest degree of polymerization was obtained with the photosensitive system using $0.5 \mathrm{~mol} \% \mathrm{CQ}$ and 1.0 or 0 . $5 \mathrm{~mol} \%$ DMAEM, but, at high concentrations such as $1.0 \mathrm{~mol} \% \mathrm{CQ}$ and, $2.0 \mathrm{~mol} \% \mathrm{DMAEM}$, the degree of polymerization decreased. This is supposed to be caused by an excessive amount of photosensitizer (polymerization initiator) ; likewise excessive increase of intensity of radiation, gives rise to quick and widespread formation of free radicals. This in turn causes substantial amounts of the monomer to be encapsulated within the polymer thus losing the ability to react and resuiting in a polymer having predominantly a small molecular weight. This is in accordance with the measurements of hardness, made with changing light intensity. DMPT, the tertiary amine corresponding to DMAEM is assumed to have the same 
action as DMAEM. Discoloration of the resin after curing using DMPT was greater than that using DMAEM.

When measuring the effect of different types of base resin monomers on the degree of polymerization, almost no differences were noted between Bis-MPEPP, $2.6 \mathrm{E}$ and $4 \mathrm{E}$, and Bis-GMA, all showing a degree of polymerization as high as $80 \%$, but with $3 G$ and UDMA the degree of polymerization was low. The low degree of polymerization with $3 \mathrm{G}$ may be due to its smaller molecular weight compared to other monomers. However, the low degree of polymerization with UDMA, which has the same molecular weight as Bis-GMA may be due to the absence of a benzene ring.

For Raman spectrum measurement of commercially available visible light curing composite resins, we put aluminum foil on top of the sample to prevent scattered light coming from the concave top of sample. The integrating time of the spectrophotometer was increased and the measurements were taken at reduced speed, following removal of fluorescence through aging.

The values obtained with Raman spectroscopy were not as different from those obtained with high speed liquid chromatography or infrared spectrophotometry ${ }^{4,8-10)}$. Judging from these results, as indicated by $\mathrm{Nasu}^{4)}$ and $\mathrm{Block}^{11)}$, an intermediate layer seems necessary for ensuring the protection of the dental pulp.

Furthermore, the manufacturers should indicate a longer irradiation time. To which extent the unreacted monomer in the bottom of the cavity is reduced by changing the irradiation condition remains to be studied. At present, the degree of polymerization of the bonding agents of commercially available composite resins in dentinal tubule seems to be related to the adhesion. The values obtained with Raman microspectroscopy were lower than the values obtained in in vitro experiments. Ethanol may cause increased polymerization in the in vitro experiments.

Raman light produces abundant fluorescence, which makes a clear reading difficult. Raman spectrum measurement of a high polymer compound is said to be a struggle against fluorescence. For removal of fluorescence, the following three methods have been reported: a) inverse Raman spectroscopy, b) elimination of fluorescence by time resolved spectroscopy ${ }^{14-17)}$, and c) near infrared Raman spectroscopy ${ }^{18)}$.

The application of laser Raman spectroscopy in dental regions is not limited to only measurement of the degree of polymerization of resins, but also other areas.

\section{CONCLUSIONS}

The characteristics of curing resin using visible light were examined photochemically. (1) The commercially available light curing units emit much unnecessary light, predominantly in the long wavelength range, apart from the photospectrum useful for curing photopolymerizable resins.

(2) Measurement of the internal hardness of cured resins showed an increase with laser output as well as an increase in deep hardness. The maximum hardness was not always increased. Furthermore, the position having maximum hardness tended to move deeper as the output was raised. 
(3) Using a laser Raman spectrophotometer, the Raman spectra of the base resins and the composite resins on the market were measured. The degree of polymerization of the commercially available composite resins was about $55-70 \%$, which indicates that there is ample room for improvement.

Determined by laser Raman microspectroscopy, the degree of polymerization of bonding agents in dentinal tubule was about $80-85 \%$.

\section{ACKNOWLEDGMENT}

The author wishes to thank Prof. Sadao Wakumoto, Ass. Prof. Hisashi Hisamitsu, Prof. Toshiyuki Miyaji, Showa University, and the members of Tokyo Institute of Technology.

\section{REFERENCES}

1) Shimomura, H., Hisamitsu, H., Wakumoto, S., Fujishima, A. and Miyaji, T. : Studies on a visible light cured composite resin-wavelength of various visible light units and curing characteristic and toughness of various visible light cured composite resins-, Japan J Conserv Dent 28: 164-181, 1985. (in Japanese)

2) Shimomura, H., Hisamitsu, H., Wakumoto, S., Fujishima, A. and Miyaji, T. : Studies on a visible light cured composite resin- the transmission spectra of humantooth and curing efficiency on the undercut area of tooth substance-, Japan J Conserv Dent 28 : 945-955, 1985. (in Japanese)

3) Shimomura, H., Hisamitsu, H., Wakumoto, S. and Fujii, Y.: Studies on a visible light cured composite resin-measuring the degree of polymerization by means of laser Raman spectroscopy-, Japan J Conserv Dent 29 : 1252-1266, 1986. (in Japanese)

4) Nasu, I., Miyake, H., Hirabayashi, S. and Hirasawa, T.: Composition of various visible light-cured composite resins and elutions of residual monomer from these cured resins, $J J$ Dent Mat 3: 655-664, 1984. (in Japanese)

5) Delange, C., Bausch, J. R. and Daridson, C. L. : The curing pattern of photo-initiated dental composites, J Oral Rehabil $7: 369-377,1980$.

6) Denyer, R. and Shaw, D. J. : Cure evaluation of visible light composite by knoop hardness measurement, $J$ Dent Res 61 : Abstract No. 833, 1982.

7) Swarts; M. L., Phillips, R. W. and Rhodes, B. : Visible lightactivated resins-depth of cure, $J$ Am Dent Assoc 106 : 634-637, 1983.

8) Asmussen, E. : Factors affecting the quantity of remaining double bonds in restorative resin polymers, Scand J Dent Res 90 : 490-496, 1982.

9) Ferracane, J. L. and Greener, E. H. : Fourier transform infrared analysis of degree of polymerization in unfilled resins, $J$ Dent Res 63 : 1093-1095, 1984.

10) Ferracane, J. L., Matsumoto, H. and Okabe, T.: Time-dependent deformation of composite resinscompositional considerations, $J$ Dent Res 64 : 1332-1336, 1985.

11) Block, W. W., Austin, J. C., Cleatonjones, P. E., Wilton-Cox, H. and Fatti, L. P. : Pulpal response to a new visible light-cured composite restorative materials, J Oral Pathol 6 : 278-287, 1977.

12) Smekal, A.: Zuschriften und vorlaufige Mitteilungen, Naturwiss 11: 873-875, 1923.

13) Raman, C. V. and Krishnan, K. S. : A new type of secondary radiation, Nature 121 : 501-502, 1928.

14) Van Duyne, R. P., Jeanmaire, D. L. and Shriver, D. F. : Modelocked laser Raman spectroscopy-a new technique for the rejection of interfering background luminescence signals, Anal Chem 46:213-222, 1974.

15) Harris, J. M., Chrisman, R. W., Lytle, F. E. and Tobias, R. S. : Sub-nanosecond time-resolved rejection of fluorescence from Raman spectra, Anal Chem 48: 1937-1943, 1976.

16) Burgess, S. and Shepherd, I. W. : Fluorescence suppression in time-resolved Raman spectra, $J$ Phys E10 : 617-620, 1977.

17) Watanabe, J., Kinoshita, S. and Kushida, T. : Fluorescence rejection in Raman spectroscopy by a gated 
single-photon counting method, Rev Sci Instrum 56 : 1195-1198, 1985.

18) Harada, I., Furukawa, Y., Tasumi, M., Shirakawa, H. and Ikeda, S. : Spectroscopic studies on doped polyacetylene and $\beta$-carotene, $J$ Chem Phys 73: 4746-4753, 1980. 


\title{
本号掲載論文の和文抄録
}

\author{
金銀パラジウム合金の $0.9 \%$ 生理食塩水中での腐食挙動について \\ 第 1 報 腐食産物の表面分析 \\ 松田浩一*, 荊木裕司*, 坂井秀行**, 宇野 豊**, 下河辺宏功** \\ 大川昭治***, 近藤清一郎***, 太田 守*** \\ *東日本学園大学齿学部第 2 保存学講座 **北海道大学齿学部第 1 保存学講座 \\ ***北海道大学歯学部崡科理工学講座
}

\footnotetext{
金銀パラジウム合金は, 我が国においてはインレー, クラウン,ブリッジ等広く臨床に使用されている。

この合金は，金，白金族含有量が十分でないので，耐 食性が問題になる。

そこで今回, 市販金銀パラジウムの食塩水中での腐食 挙動を, 電気化学的手法と光電子分光法と反射電子回折 法を用いて分析し，次の結果を得た。

1）この研究に用いた合金は, $-100 \mathrm{mV}$ 以下の電位 においては，腐食されない。
}

2）電位が $0 \mathrm{mV}$ から $300 \mathrm{mV}$ までの間ではこの合金 中の $\mathrm{Ag}, \mathrm{Cu}$ が酸化される。 $400 \mathrm{mV}$ と $500 \mathrm{mV}$ において は, 腐食表面に $\mathrm{AgCl}$ と $\mathrm{Cu}(\mathrm{OH})_{2}$ が見られる。そして, $\mathrm{AgCl}$ の量は, $\mathrm{Cu}(\mathrm{OH})_{2}$ に比べて多い。

3）この合金中の $\mathrm{Pd}, 400 \mathrm{mV}$ と $500 \mathrm{mV}$ では $\mathrm{PdO}_{2}$ に酸化される。

4)この合金中の Auは, $500 \mathrm{mV}$ までは, 酸化されな

\section{可視光線重合型レジンに関する光化学的研究}

\section{下村 博}

\section{昭和大学齒学部第二匊科保存学教室}

可視光線重合型各種コンポジットレジン並びに同照射 器の性能に関して, 光化学的見地からレーザーを用いて 実験を行い，以下のような結果を得た。

1)市販照射器の照射光スペクトル剆定を行うと共 に，各種波長のレーザーを用いた琞射実験により，レジ ンの至適重合波長域の検索を行った結果，市販照射器の 中には，肉眼的に照射光が非常にまぶしくとも,レジン の重合に関与しない不必要な光を発するものがあること が判明した。
2）アルゴンイオンレーザーで硬化させたレジンの内 部硬さを測定した結果, 至適架橋輝度の存在が確認され, 照射光の輝度の増加が必ずしも硬さの増加につながらな いことが判明した。

3）レジンの重合度をレーザーラマンスペクトルを用 いて測定する方法を確立した。市販のコンポジットレジ ンの重合度は，予想に反して低いことが判明した。また， 顕微ラマンスペクトルについても検討を加えた。 